\title{
An unusual polyp at colonoscopy
}

\author{
Andrew D Beggs, ${ }^{1}$ Michael J Coppen, ${ }^{2}$ A Muti Abulafi ${ }^{3}$
}

${ }^{1}$ St Georges University of London, London, UK

${ }^{2}$ Department of Histopathology, Croydon University Hospital, Croydon, UK

${ }^{3}$ Department of Surgery, Croydon University Hospital, Croydon, UK

Correspondence to Andrew D Beggs, abeggs@sgul.ac.uk

\section{DESCRIPTION}

A 54-year-old man presented to surgical outpatients with a 3-month history of rectal bleeding with no change in bowel habit or abdominal pain. He had a medical history of gastroenteritis. He had no family history of bowel cancer.

Colonoscopy to the terminal ileum revealed a broadbased smooth polypoid mass in the transverse colon (figure 1). Palpation using biopsy forceps showed that it was soft and not tethered to the underlying mucosa and was completely within the wall of the colon. Biopsy was performed and histological examination revealed a unilocular thin-walled submucosal lymphatic cyst lined with flat endothelial cells, typical of gastrointestinal lymphangioma (figure 2). Because colonic lymphangioma is generally considered a benign lesion consideration was given to leaving the lesion in place however it was eventually removed via snare polypectomy.

Colonic lymphangioma is rare, with only 47 cases ever reported in the literature ${ }^{12}$ and seems to be uncommon in the Western hemisphere. Their location is also highly variable, with presentation both in large bowel and in small bowel, with the predominant findings either in the mesentery or as a pedunculated mass arising from the large bowel. ${ }^{3}$ The presentation in our case is highly

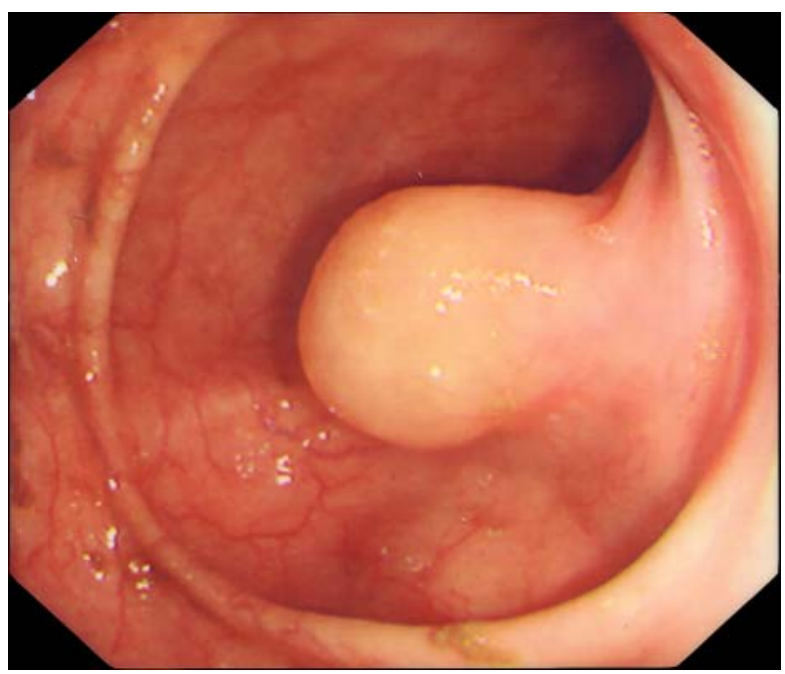

Figure 1 Image from colonoscopy of lymphangioma.

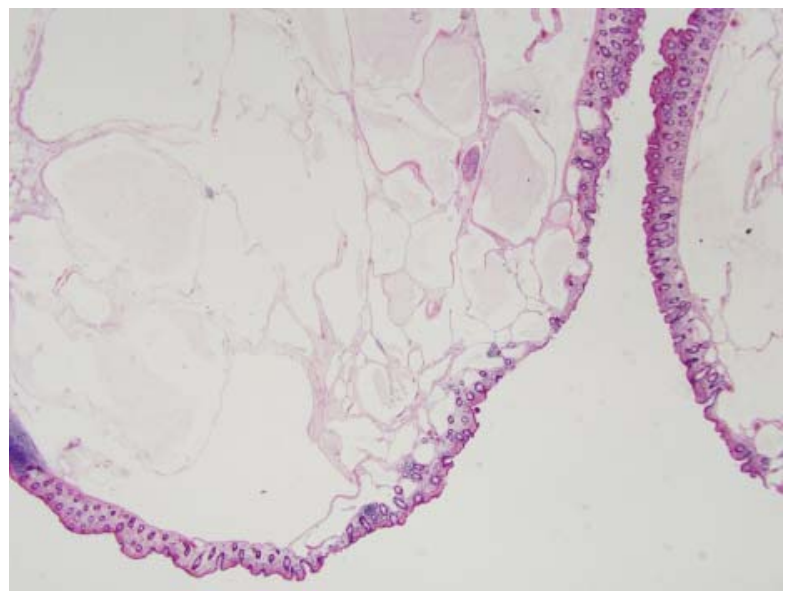

Figure 2 H\&E micrograph of lymphangioma ( $\times 10$ power).

unusual as only one other case has reported this phenomenon occurring completely within the wall of the colon. ${ }^{1}$ Colonic lymphangioma demonstrates many macroscopic features of adenomatous colorectal polyps. Awareness and recognition of these lesions are important in the differential diagnosis of colonic polyps during endoscopic examination of the colon.

\section{Learning points}

Colonic lymphangioma is rare.

- It should be considered in the differential diagnosis of large colonic polyps.

Competing interests None.

Patient consent Obtained.

\section{REFERENCES}

1. Nakagawara G, Kojima Y, Mai M, et al. Lymphangioma of the transverse colon treated by transendoscopic polypectomy: report of a case and review of literature. Dis Colon Rectum 1981;24:291-5.

2. Sato K, Maekawa T, Yabuki K, et al. Cystic lymphangiomas of the colon. $J$ Gastroenterol 1999;34:520-4.

3. Talarico F, lusco D, Negri $L$, et al. Mesenteric cystic lymphangioma treated with laparoscopic excision: case report and review of the literature. G Chir 2009;30:362-4. 


\section{BMJ Case Reports}

This pdf has been created automatically from the final edited text and images.

Copyright 2012 BMJ Publishing Group. All rights reserved. For permission to reuse any of this content visit http://group.bmj.com/group/rights-licensing/permissions.

BMJ Case Report Fellows may re-use this article for personal use and teaching without any further permission.

Please cite this article as follows (you will need to access the article online to obtain the date of publication).

Beggs AD, Coppen MJ, Abulafi AM. An unusual polyp at colonoscopy. BMJ Case Reports 2012;10.1136/bcr-2012-006886, Published XXX

Become a Fellow of BMJ Case Reports today and you can:

- Submit as many cases as you like

- Enjoy fast sympathetic peer review and rapid publication of accepted articles

- Access all the published articles

- Re-use any of the published material for personal use and teaching without further permission

For information on Institutional Fellowships contact consortiasales@bmjgroup.com

Visit casereports.bmj.com for more articles like this and to become a Fellow 